\title{
HEGEMONI BAHASA MILENEALISASI PADA SLOGAN DEMONSTRASI: ANALISIS WACANA KRITIS
}

\author{
Ibnu Ajan Hasibuan ${ }^{1)}$, Ade Irma Khairani ${ }^{2)}$ \\ ${ }^{1}$ Program Studi Linguistik Pascasarjana; Universitas Sumatera Utara, Jl. Dr. T. Mansur No. 9 Kampus Padang Bulan, Medan \\ 20222, Indonesia. \\ E-mail: ibnuhsb95@gmail.com
}

\begin{abstract}
Abstrak
Penelitian ini bertujuan untuk menganalisis praktek wacana pada slogan aksi demonstrasi yang dilakukan oleh mahasiswa sebagai fenomena baru dimasa sekarang. Dibalik selogan-slogan ditemukan adanya kekuatan dan keunikan yang menghegemoni dengan tinjauan aspek linguistik sebagai hasil ide mahasiswa untuk menyampaikan aspirasi kepada pemerintah. Metode deskriptif kualitatif digunakan untuk mengumpulkan dan menyajikan data kemudian dianalisis menggunakan pendekatan analisis wacana kritis Norman Fairclough serta memadukannya dengan pendekatan unsur psikoanalisis Freudian. Dari hasil analisis data ditemukan adanya penggunaan teks dari segi liguistik yang mana Representasi anak kalimat menunjukkan pemilihan diksi dan majas personifikasi. Selanjutnya Representasi hubungan kalimat menujukkan adanya unsur pragmatik seperti "ilokusi” dan bahasa "sarkasme". Dari seluruh pembentukkan wacana terdapat faktor yang mempengaruhi ide atau gagasan yang menghegomi bahasa. Fungsi Id ditekan oleh Ego dan Superego sebagai penyampai hasrat libido mahasiswa kedalam bentuk simbolik (slogan). Ranah simbolik tersebut menguasai pembentukan wacana. Kekuasaan hasrat menghegemoni kaum mahasiswa.
\end{abstract}

Kata kunci: Analisis Wacana Kritis; Hegemoni Bahasa; Milenealisasi.

\begin{abstract}
This research aims to analyze discourse practice of demonstration actions carried out by students as a new phenomenon in the present. Behind the slogans found strength and uniqueness that hegemony with a review of the linguistic aspects of the slogans resulting from student ideas to convey aspirations to the government. The qualitative descriptive method was used to collect and present data and then analyzed using Norman Fairclough's critical discourse analysis approach and combining it with the Freudian psychoanalytic element approach. In this study found the use of text in terms of liguistic in which the representation of the clause shows the selection of diction and the form of personification. Furthermore, the representation of sentence relationships shows the existence of pragmatic elements such as "illocution" and language "sarcasm". From all the formation of discourse there are factors that influence ideas or ideas that hegemony language. The function of Id is suppressed by Ego and Superego as conveying the desire of student libido into symbolic form (slogan). So that this symbolic realm dominates discourse. The power of that desire hegemonyed the students.
\end{abstract}

Keyword: Critical Discourse Analysis; Language Hegemony; Milenealization.

\section{PENDAHULUAN}

Praktek wacana belakangan ini memang sangat sering ditemukan sehingga menjadi gudang variabel untuk diadakannya tindak lanjut pada ranah penelitian. Masalah-masalah tersebut kerap kali menjadi perbincangan hangat dimasyarakat. Misalnya kehadiran media sosial seperti facebook, instagram, WhatsApp, dan sebagainya. Penggunaan media sosial memudahkan pekerjaan dan informasi tersempaikan sebagai contoh kegiatan demostrasi yang dilakukan oleh mahasiswa yang menggunakan slogan kampanye yang mengkritisi RUU yang dibentuk oleh pemerintah. Teknologi memudahkan informasi kegiatan tersebut sampai dimasyarakat luas. Oleh sebab itu, wacana tersebut beredar hingga menimbulkan sudut pandang dari beberapa ranah sosial Slogan aksi demonstrasi yang diaspirasikan oleh mahasiswa adalah sebagai alat komunikasi penyampaian informasi dan kritikan terhadap kebijakan pemerintah yang mengandung wacana kritis. Beragam wacana yang terdapat dalam slogan kampanye tersebut memiliki maksud agar makna yang tersirat menjadi perhatian serta mendapat respon dari 
pemerintah. Mahasiswa adalah individu atau sejumlah kelompok terpelajar yang bebas serta merdeka dalam menanggapi fenomenafenomena yang berkembang dimasyarakat. Hal ini menjadikan mereka sebagai busur tri dharma perguruan tinggi. Mahasiswa adalah penyambung aspirasi masyarakat. Mereka sudah menempatkan hati dan pikiran mereka pada masyarakat.

(Hidayatullah et al., 2018), bila dilihat dari fenomena sekarang, aksi dari slogan kampanye tersebut berbeda dari demonstrasi di masa lampau. Adanya keunikan tersendiri baik dari kritikan dan maknanya. Hal inilah penulis katakan sebagai milenealisasi bahasa. Istilah mileneal berasal dari kata millennials yang diciptakan oleh dua pakar sejarah dan penulis Amerika, William Strauss dan Neil Howe. Hasil riset dari Nielsen menggambarkan perilaku generasi akrab internet itu menjadi saah satu faktor munculnya budaya baru. Mileneal merupakan sebutan untuk kaum muda seperti halnya mahasiswa yang bebas dan dinamis. Sehingga milenalisasi bahasa sebagai proses pembentukan bahasa yang dibumbubumbui dengan situasi dan konteks masa muda mereka. Generasi ini identik dengan teknologi, khususnya internet dan media sosial. Menurut penelitian (Hidayatullah et al., 2018), generasi milenial tidak bisa dilepaskan dari penggunaan teknologi, terutama internet, karena hal itu sudah menjadi kebutuhan pokok mereka.

Hegemoni sebagai sesuatu yang membedakan suatu kelompok dalam kelas sosial. Kelas sosial yang lebih tinggi seperti borjuisme mempunyai kekuasaan yang dominan daripada kelas sosial yang rendah atau seperti kelas ploretariat. Senada dengan yang dikemukanan (Fauzan, 2014) bahwa hegemoni pada dasarnya dipahami sebagai perbedaan di mana kelompok-kelompok sosial yang dominan membentuk suatu sistem "persetujuan permanen". Konsep hegemoni menurut (Antonio, 1971) bahwa dominasi kekuasaan diperjuangkan di samping dengan kekuatan senjata, juga melalui penerimaan publik.
Kekuasaan menjadikan suatu sistem dapat diatur dengan kemauan subjeknya sendiri. Kekuasaan dapat mengontrol apa saja yang menjadi wewenangnya untuk berkuasa. Melalui bahasa, kekuasaan itu terbentuk. Hal inilah yang terjadi pada aksi demonstrasi yang mana mahasiswa sebagai actor sekaligus yang menguasai jalanan untuk menyampaikan aspirasi. Mereka tidak peduli seberapa unik dan tidak adanya korelasi makna slogan atau kritikan mereka pada kebijakan. Sehingga kehadiran mereka mampu menguasai media dan berita bagi mata publik. Inilah yang menjadikan wacana mampu menghegemoni mahasiswa menjadi terlihat unik dimata masyarakat ( et al., 2016).

Dalam analisis wacana kritis, wacana tidak hanya dipahami sebagai studi bahasa, tetapi juga dihubungkan dengan konteks yang berarti bahwa bahasa dipakai untuk tujuan praktik tertentu, termasuk praktek kekuasaan. Berdasarkan hal tersebut, Fairclough melihat wacana kritis sebagai bentuk dari praktik sosial. Sebelumnya pelitian serupa pernah dilakukan dengan objek kajian Slogan penggunanaan bahasa Inggris Perguruan Tinggi dari Telkom University (2016) dimana terdapat praktek wacana yang menunjukkan adanya ideologi Kapitalisme akan tetapi dari sudut praktek sosiokultural belum jelas adanya ditemukan. Analisis wacana kritis melihat bahasa sebagai faktor yang penting, yakni bagaimana penggunaan bahasa untuk melihat ketimpangan kekuasaan yang terjadi dalam masyarakat. Berdasarkan hal tersebut dapat dikatakan bahwa pada dasarnya wacana menjadi bagian yang tidak bisa dipisahkan dari proses dan mekanisme kekuasaan.

Penelitian ini termasuk penelitian analisis wacana kritis dengan pendekatan analisis wacana Norman Fairclough. Titik fokus perhatian Fairclough adalah melihat bahasa sebagai praktik kekuasaan. Analisis wacana melihat pemakaian bahasa tutur dan tulisan sebagai praktik sosial. Bahasa yang digunakan mahasiswa adalah salah satu praktik kekuasaan yang menguasai media sosial. 


\section{METODE PENELITIAN}

Penelitian ini bertujuan untuk menganalisis praktik sosial yang dilakukan oleh mahasiswa maupun anak muda mileneal. Analisis teks yang dilakukan berusaha untuk menemukan makna dan praktek diskursus dari representasi demonstran melalui kacamata linguistis. Analisis wacana Fairclough menintegrasikan linguistik sebagai bentuk perubahan sosial dengan memusatkan perhatian pengguna bahasa sebagai refleksi sosial dimasyarakat terkait Rancangan Undang-Undang yang menjadi kebijakan pemerintah.

Metode deskriptif kualitatif digunakan untuk mengumpulkan dan menyajikan data yang dianalisis. Pendekatan kualitatif tentunya sangat efektif senada dengan (Creswell, 2011) bahwa metode penelitian kualitatif sebagai suatu pendekatan untuk mengeksplorasi dan memahami suatu gejala sentral. Penelitian kualitatif sangat dipengaruhi oleh pandangan, pemikiran dan pengetahuan peneliti. Data dianalisis dari teks slogan para aksi demonstrasi serta meninjau bagaimana objek menyampaikan kritikannya lewat spanduk tersebut. Pada tahapan analisis perlu adanya konsep untuk mengangkat hasil analisis data, untuk itulah table Analisis wacana kritis Fairclough ini dihadirkan.

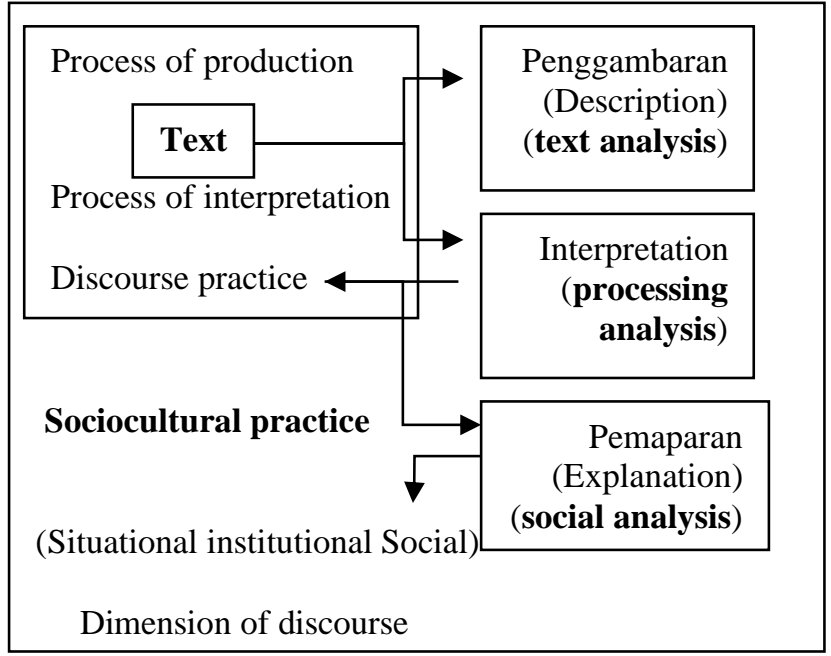

Tabel 1. Analisis wacana kritis Norman Fairclough

\section{HASIL DAN PEMBAHASAN}

Wacana sebagai bentuk praktik sosial dilakukan dengan Verbal (Utterance) atau nonverbal (teks). Wacana dianalisis dengan menggunkan analisis wacana kritis. Sebenarnya analisis wacana bukan saja menngunakan teori Fairclough semata diantaranya adanya ada Van Dijk.Akan tetapi pada data ini akan lebih baik bila Analisis fairclough digunakan sebagaimana Foucoult menyebutkan bahwa wacana sebagai praktik kekuasaan (Language Power). Hal ini dikemukan oleh (Eriyanto, 2001) bahwa Fairclough menggunakan wacana menunjuk pada pemakaian bahasa sebagai sebuah praktik sosial, lebih daripada aktivitas Individu atau untuk merefleksikan sesuatu. Pertama, wacana adalah bentuk dari tindakan, seseorang menggunakan bahasa sebagai suatu tindakan pada dunia dan khususnya sebagai bentuk representasi dari realita yang ada. Kedua, implikasi adanya hubungan timbal balik antara wacana dan struktur sosial.

Analisis (Fairclough, 1995) dibagi tiga tahapan dalam menganalisis wacana atau menelanjangi wacana diantaranya ialah Teks dimana teks diproduksi untuk mengutarakan bahasa yang dapat mempengaruhi pengguna bahasa. Kedua, Praktek Wacana (Discourse Practice) yang menjadi dimensi produksi teks dan konsumsi teks. Dan Ketiga, Praktek Sosiokultur (Sociocultural).

\section{a. Teks}

Teks sebagai bentuk representasi sesuatu yang mengandung ideology tertentu, sehingga teks dibongkar dengan melihat aspek linguistis yaitu kosakata, semantik, tata kalimat, koherensi, dan kohesivitas. Teks pada gambar pertama adalah sebagai berikut. 


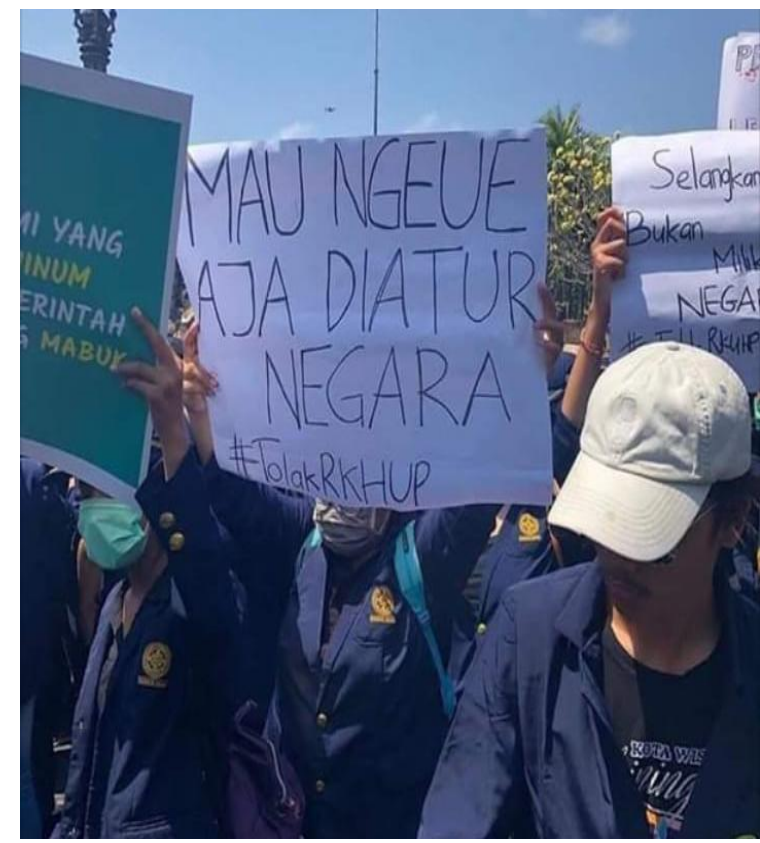

Gambar 1. Bentuk Wacana sebagai Kritikan pada RKHUP

Data diatas merupakan bentuk wacana kritikan pada pemerintah yang bertuliskan "Mau Ngeue aja Diatur Negara" adalah wacana yang menyindir pemerintah selaku penentu kebijakan. Pada wacana ini mencoba mengkrtik undang-undang yang kontroversial dimasyarakat yang isinya laki-laki dan perempuan yang hidup bersama tanpa ikatan pernikahan atau melakukan hubungan seks di luar nikah (zina) dijerat dengan pasal (417) dan (419). Orang yang berzina bukan dengan pasangan sah menikah dipidana penjara satu tahun. Bagi pasangan yang hidup bersama tanpa ikatan pernikahan atau kohabitasi dipidana enam bulan. Dengan hadirnya wacana tersebut, mahasiswa berharap bahwa pemerintah dapat mengklarifikasi undangundang tersebut mengingat masyarakat sipil tidak memerlukan pasal tersebut sebab sudah masuk ranah privasi. Wacana ini juga hampir sama dengan data spanduk lainnya seperti berikut ini.

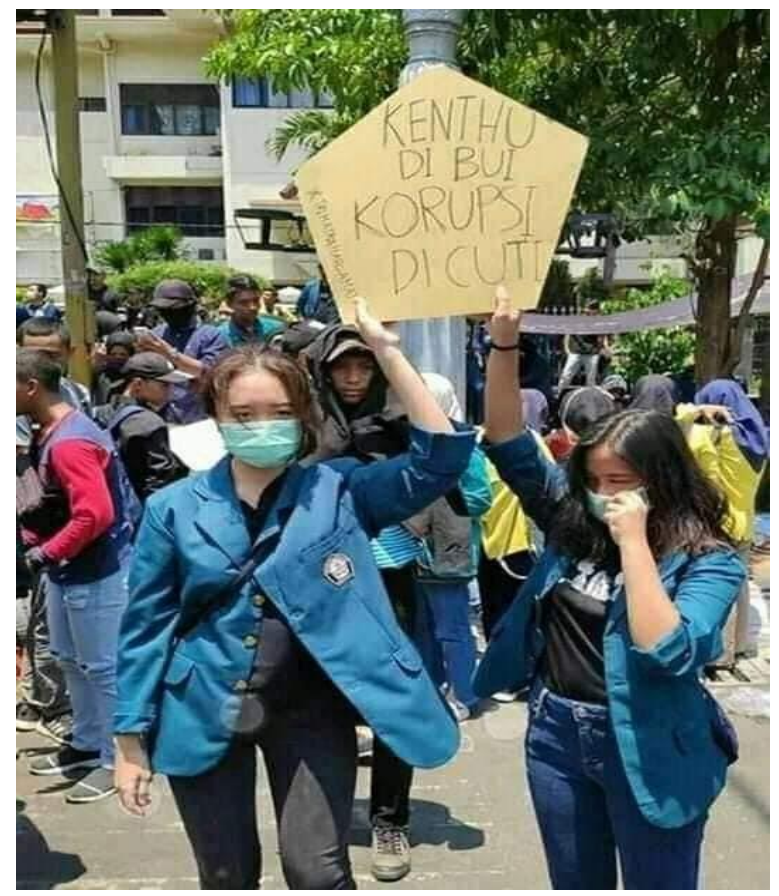

Gambar 2. Aksi Demonstrasi RUUKUHP

Pada wacana diatas menunjukkan adanya representasi dari dua pihak yaitu pemerintah dan masyarakat. Teks tersebut juga mengkritiki kebijakan yang menurut mereka tidak sesuai dengan keperluan masyarakat. Di bawah ini penulis akan tampilkan beberapa data dari wacana slogan aksi tersebut.

\begin{tabular}{llll}
\hline \multicolumn{1}{c}{ Wacana } & \multicolumn{2}{c}{ General } & \multicolumn{1}{c}{ Khusus (Milenial) } \\
\cline { 2 - 3 } & \multicolumn{1}{c}{ (a) sange dikit kenak pasal } & Kenak pasal & Sange \\
\hline (b) ada yang berdiri tegak, tapi itu & keadilan & Berdiri tegak \\
bukam keadilan, Itu titit & & \\
\hline (c) ikut demo demi instastory & Demo & Instatory \\
\hline (d) Pelemahan KPK mengalahkan & Pelemahan KPK & Syahwat pacarku \\
& lemah syahwat pacarku & & \\
\hline (e) kalo seks bebas dipenjara, siapa & Kerja digedung DPR & Seks bebas \\
yang kerja di gedung DPR & & \\
\hline (f) Kenthu di Bui, Korupsi Dicuti & Korupsi dicuti & Kenthu \\
\hline (g) Mau Ngeue aja diatur Negara & Diatur & Ngeue \\
\hline
\end{tabular}




\begin{tabular}{|c|c|c|c|}
\hline (h) & $\begin{array}{l}\text { Aku ingin yang yangan tanpa takut } \\
\text { tangkap Polisi }\end{array}$ & Tangkap polisi & Yang-yangan \\
\hline (i) & $\begin{array}{l}\text { Selangkanganku Bukan milik } \\
\text { Negara }\end{array}$ & Milik negara & Selangkangan \\
\hline (j) & Front Pembela suami Sangean & Front pembela & Suami sangean \\
\hline$(k)$ & $\begin{array}{l}\text { cukup cintaku saja yang kanda, KPK } \\
\text { jangan }\end{array}$ & KPK jangan & Kandas \\
\hline (l) & $\begin{array}{l}\text { Negara tidak memfasilitasi rindu, } \\
\text { tapi mencampuri urusan saat kita } \\
\text { bertemu }\end{array}$ & Negara Mencampuri & Rindu dan bertemu \\
\hline (m) & $\begin{array}{l}\text { Undang-undangmu Lebih Kejam } \\
\text { daripada Undangan mantan }\end{array}$ & Undang-undang & Undangan mantan \\
\hline
\end{tabular}

Table 2. Pembentukan Wacana Slogan Demonstran

\section{b. Representasi Anak Kalimat}

Apabila dilihat dari aspek kebahasaannya, spanduk tersebut sarat dengan makna. Pembentukan kalimat terjadi dua bentuk yang mana frasa formalis dan kedua adalah kata yang aribiter. Seperti pada data (1g) "Mau ngueu aja diatur' dari Morfem ngueu adalah kata yang dibentuk dimana konotasi menyimpan makna yang sebenarnya agar tidak terlihat publik sebagai bahasa yang negatif (tabu). Penggunaan kata tersebut semuanya huruf vokal. Dalam artian tidak penting dari bentuk katanya yang penting adalah makna katanya. "Ngeue (1g)" dan "Kenthu" (1f)" memiliki arti "berhubungan lawan jenis" yang diatur oleh pemerintah dalam RUU.

Dapat dilihat adanya kesan negatif yang merepresentasikan pemerintah yang telalu mengatur persoalan privasi dan minimnya demokrasi serta ideologi feodalisme menurut asumsi mereka sendiri. Sementara korupsi yang merajalela akan dicuti ataupun pelaku koruptor tidak ditindak keras. Sementara itu penggunaan bahasa pada bagian kedua terdapat adanya bentuk sarkasme ketimbang wacana pertama.

\section{c. Representasi Dalam Kombinasi Anak Kalimat}

Kenyataan biasanya terbentuk dari gabungan kalimat satu dengan yang lainnya. Kombinasi dari wacana diatas menunjukkan adanya gabungan antara kosakata yang dibuat mahasiswa dengan bahasa yang unik "Kenthu" dan kosa kata bahasa yang mengandung metafora "Korupsi di Cuti". Pada wacana ini terkandung unsur pragmatik seperti yang dijelaskan (Deborah, 2007) mengatakan bahwa unsur-unsur pragmatik dalam sumbangan terbesar Austin, yaitu berupa tindak tutur lokusi, ilokusi, dan perlokusi. Pada kalimat tersebut mengandung ilokusi (makna yang tersimpan). Produser seolah sudah meyakini bahwa pemerintah sebagai mayoritas pelaku korupsi.

\section{d. Relasi}

Unsur relasi yang berhubungan sebagaimana produser teks dan partisipan (pengguna media sosial, pemerintah, dan masyarakat) ditampilkan dalam teks solagan tersebut mengenai kebijakan pemerintah dalam merancang Undang-undang seperti data (1i) "Selangkanganku Bukan milik Negara". Penentuan dari relasi ini adalah bagaimana pembuat wacana manyampaikan kritikannya pada pemerintah yang menggambarkan kesibukan pemerintah mengurusi privasi masyarakat "selangkangku" yang diatur oleh UU.

\section{e. Identitas}

Pada titik ini ditemukan adanya identitas anak muda yang memiliki relevansi bahwa kehadiran kebijakan selaku pembuat kebijakan mesti diklarifikasi apakah khalayak dapat menerima peraturan tersebut. Unsur identitas memperlihatkan identitas mahasiswa sebagai penyambung hati masyarakat dan identitas pemerintah yang terlalu mengurusi privasirakyat sementara pelaku korupsi didominasi kalangan pemerintah dan kelas atas seperti data (1h) "Aku ingin yang yangan tanpa takut tangkap Polisi” Dalam aspek 
gramatikal, nilai relasional ini bisa dilihat dari beberapa poin gramatikal yang digunakan.

Pertama, bentuk kalimat yang terdiri dari tiga bentuk yaitu deklaratif, pertanyaan gramatikal seperti data (1L) "Negara tidak memfasilitasi rindu, tapi mencampuri urusan saat kita bertemu", dan imperative seperti data (1K) "cukup cintaku saja yang kanda, KPK jangan". Masing-masing bentuk kalimat memiliki implikasi makna yang berbeda-beda. Kedua, modalitas yang terkait dengan otoritas penulis atau pembicara. Modalitas ini mengandung dua dimensi tergantung arah orientasi otoritas tersebut. Modalitas pertama disebut modalitas relasional yang berarti otoritas partisipan dalam relasinya dengan yang lain. Modalitas kedua disebut modalitas ekspresif yang menunjuk pada evaluasi kebenaran dari pembicara atau penulis seperti data (1h) "Aku ingin yang yangan tanpa takut tangkap Polisi". Ketiga, penggunaan kata ganti (pronoun) yang bisa menunjukkan relasi sosial yang dibangun dalam teks seperti (1m) Undang-undangmu Lebih Kejam daripada Undangan mantan (Conley \& Said, 1985).

Dari penjelasan diatas menunjukkan adanya pembentukan susunan gramatikal yang tidak teratur akan tetapi pengimplikasikan makna yang tersampaikan lewat kosakata yang khusus tersebut. Data menunjukkan adanya dominasi kosakata yang sebetulnya lebih berpihak pada kebutuhan seksualitas dan hiruk pikuk anak muda yang lebih kepada masalah hubungan. Hal inilah perlu adanya penarikan kesimpulan bahwa mayoritas produser teks cenderungmengeluarkan ide dari emosi libidonya sebagaimana dapat ditinjau dari sisi Freudian pada bagian praktik sosial berikutnya.

\section{f. Praktek Wacana (Discourse Practice)}

Discourse practice merupakan dimensi yang berhubungan dengan proses produksi dan konsumsi teks. Proses produksi teks lebih mengarah pada si pembuat teks tersebut. Proses ini melekat dengan pengalaman, pengetahuan, kebiasaan, lingkungan sosial, kondisi, keadaan, konteks, dan sebagainya yang dekat pada diri atau dalam si pembuat teks.
Aksi demonstrasi tersebut sebenarnya cukup sistematis dan terstruktur. Sebelum turun ke lapangan biasanya dibutuhkan manajemen aksi dan konsolidasi untuk memobilisasi massa aksi. Akan tetapi masih banyak mahasiswa yang tidak tahu substansi dan esensi dari tujuan aksi tersebut. Sehingga tidak serta merta wacana dalam memproduksi teks pada slogan sebatas ide yang muncul dari benak pikiran mahasiswa. Bahasa yang hadir merupakan bahasa yang mendominasi perilaku dan realitas anak muda yang cenderung kepada hasrat yang meluapluap seperti data berikut "ikut demo demi instastory dan "Pelemahan KPK mengalahkan lemah syahwat pacarku". Bisa dikatakan keinginan untuk berpartisipasi dalam membuat wacana adalah penyampaian hasrat semata. Dalam psikoanalisis Sigmund freud alam bawah sadar "yang tak tampak" diistilahkan Freud sebagai $I d$ atau Das Es, sementara "yang tampak" adalah ego dan superego meskipun memang sebagian superego juga tak tampak. Ini mengingat, seksualitas sebagaimana karakter yang dibawa libido itu sendiri, yakni sebagai "insting hidup", sementara seksualitas atau hubungan seks adalah sarana untuk melanggengkan kehidupan: "reproduksi". Hasrat membudal (Id) kedalam ranah simbolik (Spanduk). Inilah Jacques Lacan disebut sebagai pemenjara Id kedalam kerangkeng simbolik. Di satu sisi ia harus terus menekan libidonya, sementara kultur kosmopolit terus memprovokasi untuk membebaskan libidonya; dan di sisi lain ia harus terus menjaga (membangun) peradaban.

Dalam hal ini produksi teks lebih dominan ke arah seksualitas sehingga banyak kosakata yang berhubungan dengan hubungan badan mengingat kosakata yang menghegemoni ialah RUU pasal (417) dan (419). Mereka tidak perduli apakah partisipan mengerti atau tidak kosakatanya yang terpenting ialah aspirasi tersampaikan tanpa mengevaluasi. Sehingga perilaku psikologi anak milenal sekarang cenderung beraplikasi pada libido yang berlebihan tidak penting apakah betul masyarakat sudah paham dengan pasal tersebut. 


\section{g. Praktik Sosiokultural (Sociocultural Practice)}

Fairclough menegaskan bahwa "Social structures not only determines social practice, they are also a product of social practice. And more particularly, social structures not only determine discourse, they are also a product of discourse". Dalam hal ini, struktur sosial berperan penting dalam praktek sosial juga memproduksi wacana. Fairclough membagi atas tiga sub dari praktik sosial diantaranya ialah situasional, institusional, dan sistem sosial.

\section{h. Situasional}

Setiap teks dihasilkan dari suatu kondisi atau suasana yang khas dan unik sehingga teks bisa saja berbeda dengan teks yang lain. Apabila teks dipahami sebagai bagian dari tindakan, maka sesungguhnya tindakan tersebut adalah bentuk dari respon konteks sosial tertentu (Eriyanto, 2001). Perhatikan wacana dari data data $(1 \mathrm{k})$ cukup cintaku saja yang kandas, KPK jangan dan data (1M) Undang-undangmu Lebih Kejam daripada Undangan mantan, seolah-olah kehadiran wacana situasi individu maupun pribadi produser memang sesusai dengan konteks kenyataan.

Demontrasi tersebut merupakan mobilisasi massa yang cukup besar. Tentunya akan banyak individu yang berbeda sesuai situasi dan emosionalnya menjadi partisipan. Dalam kehidupan berorganisasi salah satunya akan ada yang disebut senior dan junior. Begitu juga dengan perilaku (behavior) setiap individu. Barangkali saat itu ada yang sedang menjalani hubungan dan ada yang masih single atau dalam istilah milenealnya pas sayangsayangnya ditinggal. Emosional inilah yang mewakili ide dan konsep dalam memproduksi wacana atau teks.

\section{i. Institusional}

Aksi massa yang diadakan oleh mahasiswa tersebut merupakan mobilisasi massa dengan menggunakan aliansi. Di Wilayah Medan sendiri hampir seluruh institusi atau universitas baikswasta maupun negeri ikut serta dari berbagai latar. Kita tidak tahu apakah mereka punya izin dan legalitas dalam menggelar aksi akan tetapi inilah yang mereka sebut sebagai kesadaran sosial dalam menyikapi kebijakan pemerintah.

Selanjutnya, mobilisasi massa sebagian bukan dari hasil rapat yang didakan melainkan isu dan kabar yang beredar. Sehingga akan ada masalah yang internal dalam aksi tersebut. Beberapa peserta yang ditanya oleh penulis menyatakan bahwa kehadirannya adalah atas kesadaran dan atas nama solidaritas. Hal ini tentu menjadi masalah baru yang muncul. Sebab akan terjadi keterpecahan aksi.

\section{j. Sistem Sosial}

Situasi politik dan budaya menjadi salah satu faktor mendorong adanya aksi massa melihat tahun-tahun belakangan ini sudah jarang aksi terjadi guna mengkritisi kebijakan yang menyimpang dari pemerintah menurut anak muda atau mahasiswa. Keberadaan aksi yang cukup besar ini menjadi bukti selama ini kaum intelektual tidak serta diam dan tidur dialam mimpinya. akan tetapi produksi teks yang muncul adalah sebenarnya kurang lebih kepada pemusatan hasrat individu.

\section{KESIMPULAN}

Analisis Norman Fairclough menghadirkan hasil analisis wacana yang cukup membuktikan perilaku produser teks. Data yang dianalisis diatas menunjukkan adanya pembentukan wacana lewat pendekatan linguistis dimana terdapat beberapa bentuk pragmatik seperti ilokusi dan adanya metafora yang mengandung makna sarkasme. Sehingga identitas, relasi, representasi hubungan kalimat dan pada representasi anak kalimat menunjukkan adanya pembentukan wacana yang masih minim untuk tercapainya serta tersampainya aspirasi pada pemangku kebijakan. Akan tetapi, wacana yang dihadirkan oleh slogan tersebut mampu menarik perhatian masyarakat umum terkhusus media sosial. Keunikan dari pemilihan kata serta hubungan kata yang mendominasi bahasa milenaeal mampu menunjukkan representasi dan tujuan wacana tersebut.

Wacana pada slogan tersebut dari sudut praktik wacana Fairclough menunjukkan 
adanya unsur psikologis dari sisi Freudian dimana hasrat emosional libido anak muda terkhusus mahasiswa masih dominan kepada Ego dan Super Ego yang mencoba menekan Id. Sehingga dalam memproduksi wacana, Superego berusaha menyatukan antara "bahasa" dengan jouissance "kenikmatan". Artinya hasrat membudal (Id) kedalam ranah simbolik (Spanduk). Inilah Jacques Lacan disebut sebagai pemenjara Id kedalam kerangkeng simbolik. Akhirya bahasa yang digunakan pada wacana slogan tersebut tentunya lebih kepada kosakata baru sesuai masa muda mereka yang penuh dengan hasrat yang membudal. Dalam artian kosakata itu disebut sebagai bahasa anak muda yang menguasai unsur psikologis yang menghegemoni seluruh aspirasi serta tindakan mahasiswa dalam menyampaikan kritikan terhadap pemerintah.

\section{REFERENSI}

Antonio, G. (1971). Selection of Prison Notebook. In Lawrence and Wishart (p. 280). Lawrence nda Wishart.

Conley, T., \& Said, E. W. (1985). The World, the Text, the Critic. SubStance, 14(1), 98. https://doi.org/10.2307/3684960

Creswell, J. (2011). Research design: Qualitative, quantitative, and mixed methods approaches. In Sage (Issue October).

Deborah, S. (2007). Ancangan Kajian Wacana. In Pustaka Pelajar (p. 270). Pustaka Pelajar.

Eriyanto. (2001). Analisis Wacana. In Lkis (p. 290). Lkis.

Fairclough, N. (1995). Critical Discourse Analysis: The Critical Study of Language. In Pearson (p. 360). Pearson.

Fauzan, U. (2014). Analisis Wacana Kritis dari Model Faiclough hingga Mils. Jurnal Pendidikan, 6(1), 1-15.

Hidayatullah, S., Waris, A., \& Devianti, R. C. (2018). Perilaku Generasi Milenial dalam Menggunakan Aplikasi Go-Food. Jurnal Manajemen Dan Kewirausahaan, 6(2),
240-249.

https://doi.org/10.26905/jmdk.v6i2.2560

Kristiani Samosir, D., Kurnia Nurhayati, I., \& Maulana, S. (2016). Hegemoni Penggunaan Bahasa Inggris Dalam Slogan Perguruan Tinggi (Analisis Wacana Kritis Fairclough Pada Slogan Dua Universitas Swasta Di Kota Bandung). Jurnal Sosioteknologi, 15(1), 124-135.

https://doi.org/10.5614/sostek.itbj.2016.1 5.1 .11

Said, Edward W. 1983. The World, the Text and the Critic. Cambridge, Massachussets: Harvard University Press.

Wahyu, BN. 2019. Libido yang Ditekan, Pelajar dan Mahasiswa yang Barbar. Sanglah Institute diakses pada https://www.sanglah-institute.org 